\title{
POPULATION AGING AND THE POSSIBILITY OF A MIDDLE-INCOME TRAP IN ASIA
}

Joonkyung Ha and Sang-Hyop Lee

NO. 536

February 2018
ADB ECONOMICS WORKING PAPER SERIES 
ADB Economics Working Paper Series

\section{Population Aging and the Possibility of a Middle-Income Trap in Asia}

Joonkyung $\mathrm{Ha}$ and Sang-Hyop Lee

No. 536 | February 2018
Joonkyung Ha (jha@hanyang.ac.kr) is a professor at the Division of Economics, Hanyang University. Sang-Hyop Lee (leesang@hawaii.edu) is a professor at the

Department of Economics, University of Hawaii at Manoa.

This paper has been prepared as background material for the Asian Development Outlook 2017 theme chapter on Transcending the Middle-Income Challenge under the guidance of Donghyun Park. 
(c) 2018 Asian Development Bank

6 ADB Avenue, Mandaluyong City, 1550 Metro Manila, Philippines

Tel +632632 4444; Fax +6326362444

www.adb.org

Some rights reserved. Published in 2018.

ISSN 2313-6537 (print), 2313-6545 (electronic)

Publication Stock No. WPS189235-2

DOI: http://dx.doi.org/10.22617/WPS189235-2

The views expressed in this publication are those of the authors and do not necessarily reflect the views and policies of the Asian Development Bank (ADB) or its Board of Governors or the governments they represent.

ADB does not guarantee the accuracy of the data included in this publication and accepts no responsibility for any consequence of their use. The mention of specific companies or products of manufacturers does not imply that they are endorsed or recommended by ADB in preference to others of a similar nature that are not mentioned.

By making any designation of or reference to a particular territory or geographic area, or by using the term "country" in this document, ADB does not intend to make any judgments as to the legal or other status of any territory or area.

This work is available under the Creative Commons Attribution 3.0 IGO license (CC BY 3.0 IGO)

https://creativecommons.org/licenses/by/3.0/igo/. By using the content of this publication, you agree to be bound by the terms of this license. For attribution, translations, adaptations, and permissions, please read the provisions and terms of use at https://www.adb.org/terms-use\#openaccess

This CC license does not apply to non-ADB copyright materials in this publication. If the material is attributed to another source, please contact the copyright owner or publisher of that source for permission to reproduce it. $A D B$ cannot be held liable for any claims that arise as a result of your use of the material.

Please contact pubsmarketing@adb.org if you have questions or comments with respect to content, or if you wish to obtain copyright permission for your intended use that does not fall within these terms, or for permission to use the ADB logo.

Notes:

In this publication, "\$” refers to US dollars.

ADB recognizes "China" as the People's Republic of China.

Corrigenda to ADB publications may be found at http://www.adb.org/publications/corrigenda. 


\section{CONTENTS}

TABLES, FIGURES, AND BOXES iv

ABSTRACT V v v v v

$\begin{array}{ll}\text { I. INTRODUCTION } & 1\end{array}$

II. STRUCTURE OF DEMOGRAPHY-DRIVEN MIDDLE-INCOME TRAP 4

A. $\quad$ Related Studies 4

B. Three Conditions for Demography-Driven Middle-Income Trap 5

III. TESTING FOR CONDITIONS OF DEMOGRAPHY-DRIVEN MIDDLE-INCOME TRAP 6

A. $\quad$ Condition (1): Support Ratio Matters for Economic Growth 6

B. Condition (2): Development Causing Low Fertility-Quantity-Quality Trade-Off 9

C. Condition (3): Low Fertility Leading to Too Low Support Ratio for Catch-Up 11

D. Evaluating the Possibility of a Middle-Income Trap in Asia 14

E. Effects of Extending Retirement Age 16

IV. WHAT NATIONAL TRANSFER ACCOUNTS TELL ABOUT DEMOGRAPHYDRIVEN MIDDLE-INCOME TRAP

$\begin{array}{lr}\text { VI. CONCLUSION } & 20\end{array}$

$\begin{array}{ll}\text { REFERENCES } & 23\end{array}$ 


\section{TABLES AND FIGURES}

\section{TABLES}

$1 \quad$ Support Ratio and Growth Rates 6

2 Support Ratio and National Saving $\quad 7$

3 Support Ratio and Investment Rate 7

$4 \quad$ Support Ratio and National Saving by Subregion in Asia (1): Central and East Asia 8

5 Support Ratio and National Saving by Subregion in Asia (2): South and Southeast Asia 8

6 Support Ratio and Investment Rate by Subregion in Asia (1): Central and East Asia 9

$7 \quad$ Support Ratio and Investment Rate by Subregion in Asia (2): South and Southeast Asia 9

8 Gross Domestic Product per Capita, Level of Human Capital, and Fertility 10

9 Gross Domestic Product per Capita, Level of Human Capital, and Fertility 10

10 Gross Domestic Product per Capita, Level of Human Capital, and Fertility 11 by Subregion in Asia (Model 2)

11 Elasticity of Fertility with Respect to Level of Development by Income Group 11

12 Steady State Support Ratios for Retirement Age 65 and 70 for Asia 18

13 Correlation between Major Variables from National Transfer Accounts and Others 20

\section{FIGURES}

$1 \quad$ Share of Population Age 15-64 (x-axis) and Gross Domestic Product per Capita for the People's Republic of China, Japan, and the Republic of Korea

2 Share of Population 15-64 for Asian Economies and Western Europe and North America Total Fertility of Asian Economies and Western Europe and North America Gross Domestic Product per Capita as a Ratio of the United States for Asian Economies and Western Europe and North America

$5 \quad$ Structure of Demography-Driven Middle-Income Trap 5

$6 \quad$ Current Support Ratio and the Steady State Support Ratio 13

$7 \quad$ Gap between Actual and Steady State Support Ratios for Selected Countries 14

$8 \quad$ Support Ratio and Its Steady State Value: ADB Regional Member Economies 15 and Macau, China

9 Gross Domestic Product per Capita and Steady State Support Ratio 17 for Asian Economies and Others

10 Fertility and Human Capital (left, PWT 9.0); Human Capital Spending (middle, NTAs); 19 and Consumption by Age 0-24 (right, NTAs)

$11 \quad$ Fertility and Change Rate of Support Ratio for 2015-2035 (left, NTAs), 2015-2055 20 (middle, NTAs), 2014 to Steady State (right, the model) 


\begin{abstract}
We present three conditions for a demography-driven middle-income trap and show that many economies in East, South, and Southeast Asia satisfy all of them. The conditions are (1) support ratiothe ratio of workers to consumers-matters for economic growth, (2) economic development accompanies more investment in human capital and lower fertility due to the quantity-quality tradeoff, and (3) current low level of fertility corresponds to too low support ratios for keeping up with the frontier economies in the long run. The panel analyses for 178 countries, among which 30 are ADB developing member economies, show that (i) and (ii) are satisfied for Asia with higher elasticity than others. As for (iii), we set up a dynamic model for simulations, showing that about two-thirds of ADB members have unsustainable level of support ratios, implying possibilities of a middle-income trap due to demographic headwinds in the future.
\end{abstract}

Keywords: demography, fertility, middle-income trap, national transfer accounts, support ratio

JEL codes: J11, 011,053 


\section{INTRODUCTION}

Most Asian countries have been experiencing rapid demographic transitions for the last several decades, leading to huge changes in economic environment. As has been pointed out by many researches, including Bloom, Canning, and Malaney (1999); Lee, Mason, and Park (2012); and Ha and Lee (2016), this change in age structure has created large demographic dividends for the Asian economies: increases in labor supply and savings due to faster increase in the number of workers compared with the number of consumers.

However, from 2014 to 2017, countries like the People's Republic of China (PRC) and the Republic of Korea have begun to face a totally different type of demographic change: negative demographic dividends due to shrinking share of workers in population, which Japan has already experienced since the early 1990s. Moreover, a number of other Asian economies are also expected to face a similar type of demographic headwinds in the 21st century. Figure 1 shows that Japan, the Republic of Korea, and the PRC have all experienced rising gross domestic product (GDP) per capita, but Japan has been more or less stagnating ever since the share of working-age population (age 15-64) started to decline. Our concern here is what will happen to the Republic of Korea and the PRC where the age structure is going to follow the path of Japan.

Changes in the direction of demographic dividends in Asia are occurring much faster than any other continents in the world, meaning that Asia has already exploited the benefits of demographic transition almost up to the limit. Figure 2 shows that Asia's share of working population has reached the top level by 2015, reflecting the rapid decline of fertility in this region (Figure 3).

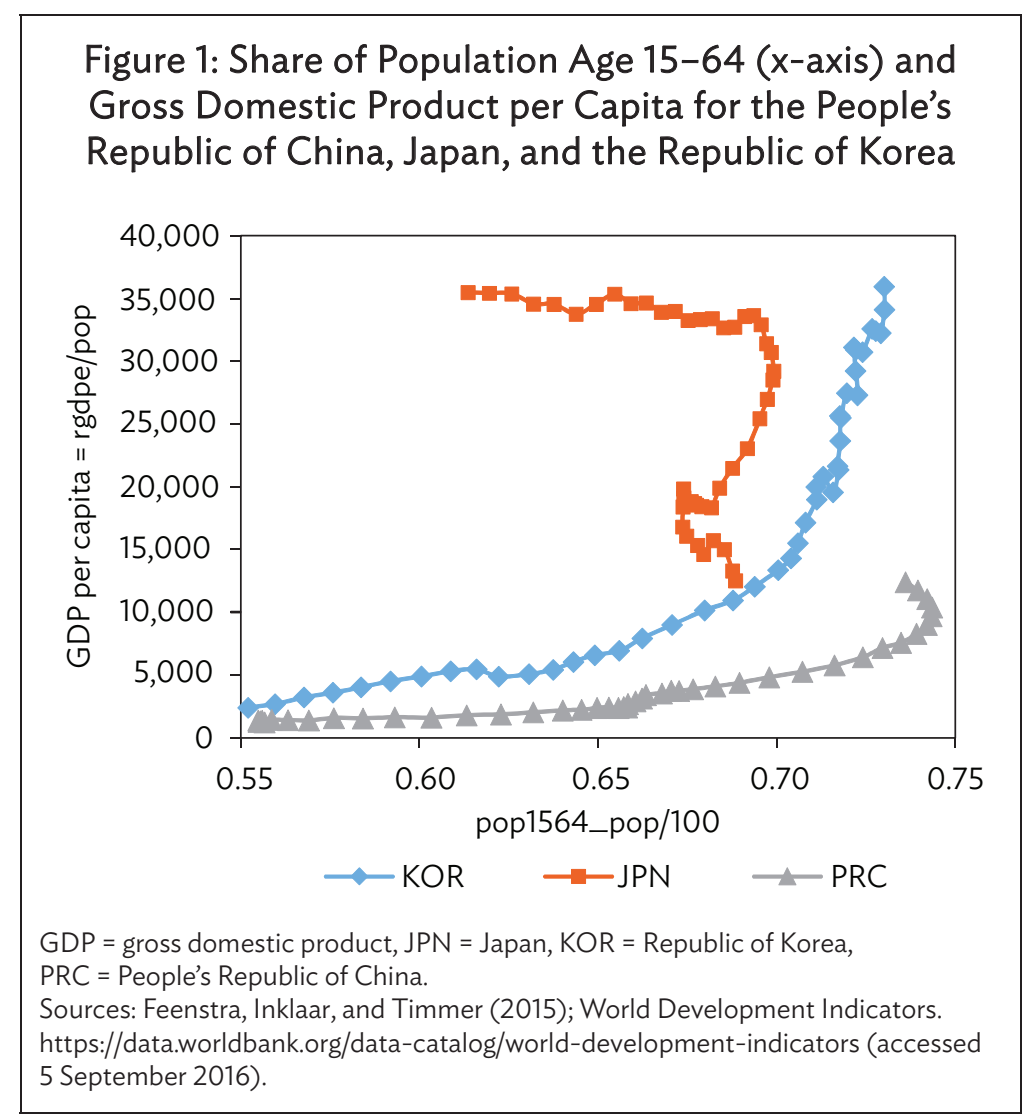




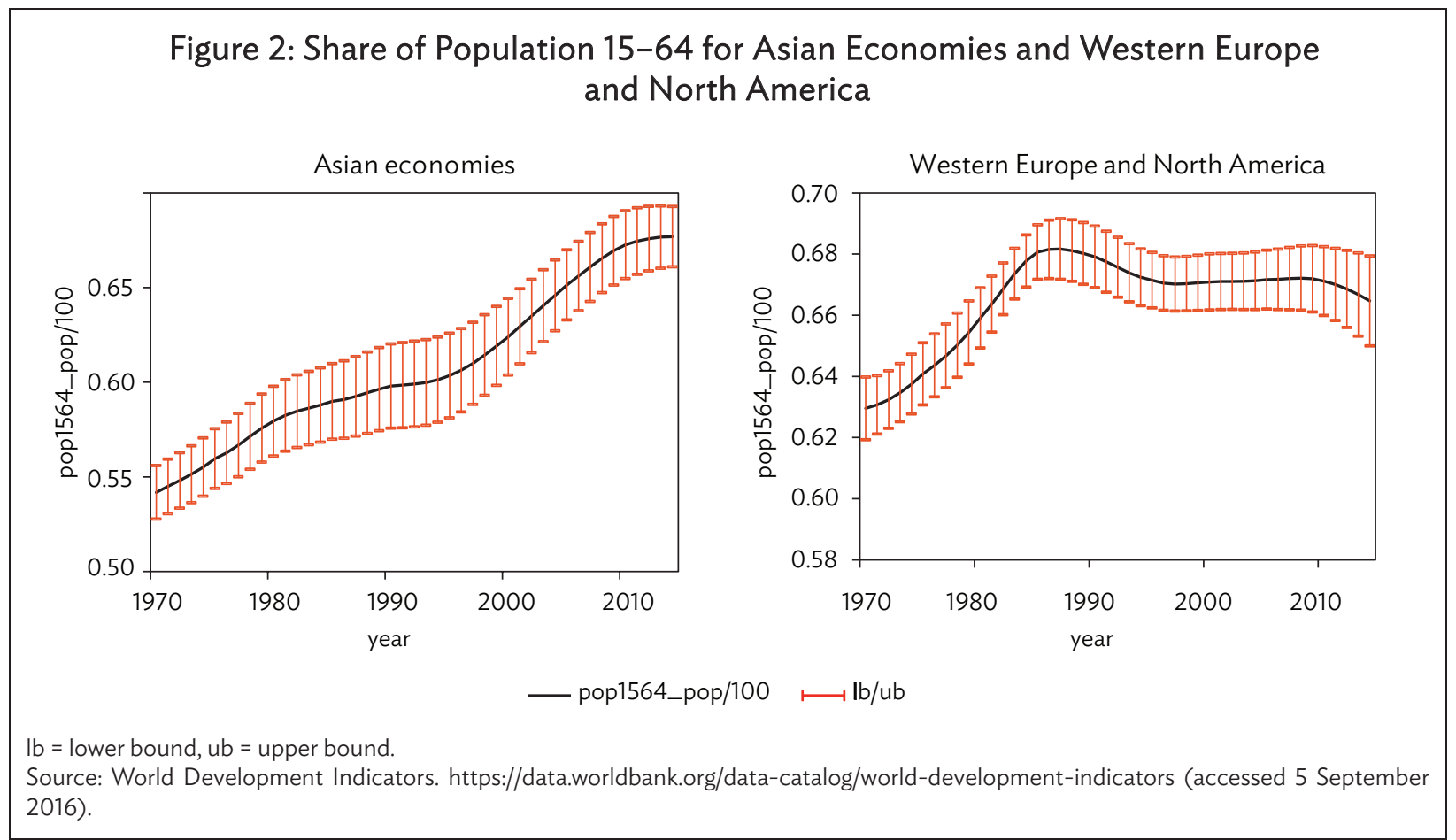

Figure 3: Total Fertility of Asian Economies and Western Europe and North America
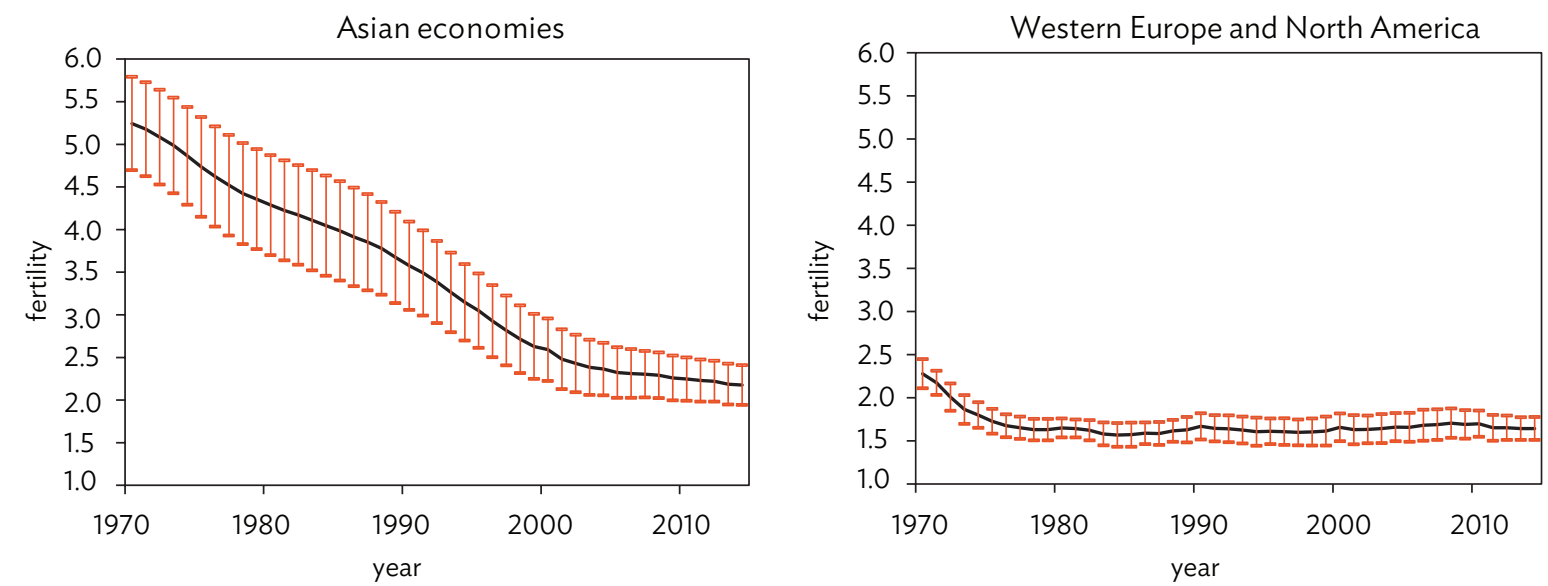

- fert

$\longmapsto \mathrm{lb} / \mathrm{ub}$

fert $=$ total fertility, $l b=$ lower bound, $u b=$ upper bound .

Source: World Development Indicators. https://data.worldbank.org/data-catalog/world-development-indicators (accessed 5 September 2016).

However, unlike Europe or North America, many Asian economies are not fully developed yet (Figure 4). This naturally raises the following question: What happens to Asia if it gets too old before getting rich? If being old means hardships in economic growth, then the answer could be that Asia is getting into a "middle-income trap" due to demographic factors. 
Figure 4: Gross Domestic Product per Capita as a Ratio of the United States for Asian Economies and Western Europe and North America
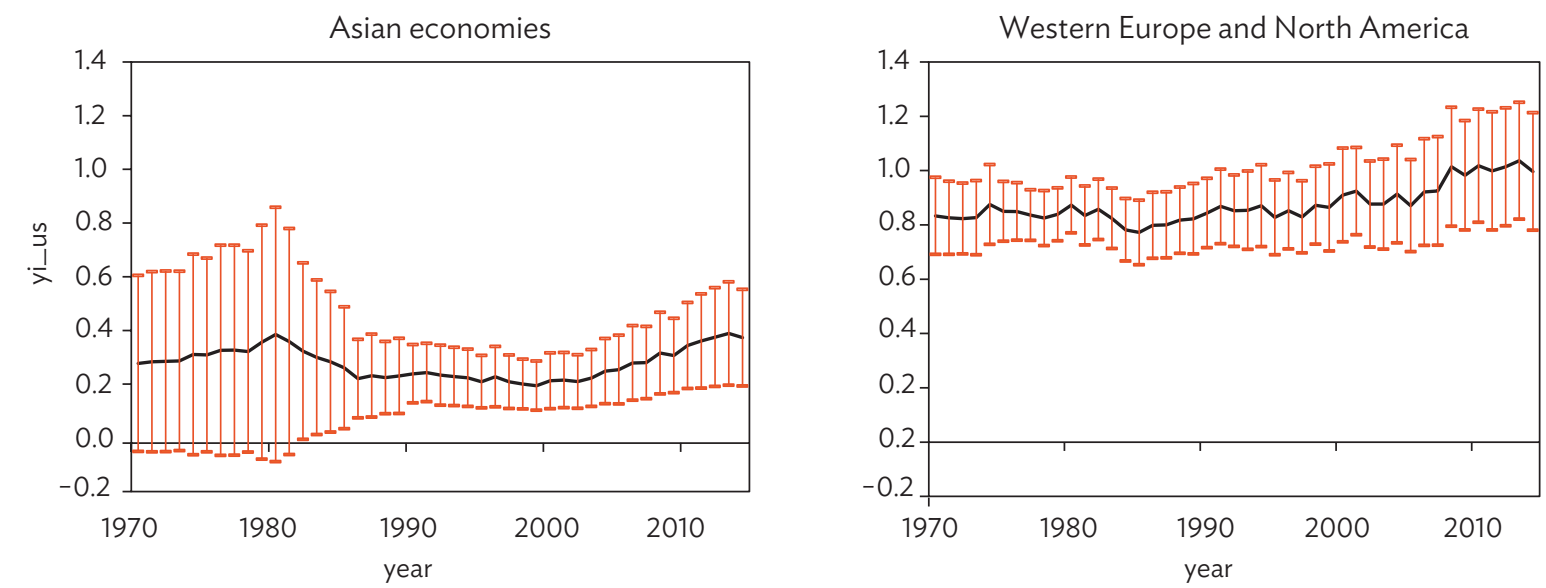

—yi_us $\longmapsto l b \_u b$

$\mathrm{lb}=$ lower bound, $\mathrm{ub}=$ upper bound, yi_us = gross domestic product per capita as ratio. Source: Feenstra, Inklaar, and Timmer (2015).

Here, we focus on the possibility of a demography-driven middle-income trap of Asian countries. As for middle-income trap, using a transition matrix analysis, Han and Wei (2016) argue that a middle-income country that grows at the average or median rate of the middle-income group will clearly and surely become a high-income country, reaching and surpassing the living standard in today's United States or France. Im and Rosenblatt (2013) also found no support for the notion of a middle-income trap. However, from the viewpoint of demographic dynamics, the notion that middleincome trap is not found reflects the data for the last several decades when demographic factors played a positive role for Asian countries. Indeed, Han and Wei (2016) point out that fast-growing countries had a relatively large working-age population, which we see as only temporary.

The possibility of a demography-driven middle-income trap has been proposed by Ha and Lee (2016), where the role of support ratio-the number of workers as a ratio of the number of consumers-in the process of economic convergence has been analyzed using the panel data of more than 100 countries. They argue that the level of support ratio is closely related with the speed of convergence or growth rate of GDP per capita, and the level of economic development and average human capital has negative relationship with fertility. As the economy grows, fertility declines, ultimately leading to low support ratios and lower speed of convergence, which implies the possibility of a middle-income trap.

In this research, we first present more extended analyses of Ha and Lee (2016) for different regions and income groups for Asia, then we add analyses on the link between fertility and support ratios for Asia. This additional work is important because fertility affects support ratios in different ways over time. In the short term, a decline in fertility always raises support ratio. However, in the long run, it depends on the current level of support ratio and other demographic variables. We model such dynamics to analyze long-run effects of fertility for each country to analyze if middle-income trap is likely to come or not. 
Moreover, we discuss what the national transfer accounts (NTAs) data tells about the middleincome trap. We show that the NTAs data show more vivid and clearer picture for intergenerational resource allocation and the dynamic relationship between fertility and support ratios.

The structure of this paper is as follows. Section II discusses related researches. Section III presents the structure of demography-driven middle-income trap, including the dynamics of support ratios. Section IV shows empirical results. Section $V$ discusses what NTAs tell about this issue, and section $\mathrm{VI}$ concludes.

\section{STRUCTURE OF DEMOGRAPHY-DRIVEN MIDDLE-INCOME TRAP}

\section{A. Related Studies}

According to Han and Wei (2016), who reject the unconditional notion of a "middle-income trap," the term "middle-income trap" was invented by Gill and Kharas (2007). However, similar concepts, for example, a nonconvergence trap, have been developed earlier in the 1990s modeling various sources of the trap. These theories are all based on the premise that developing countries could face stagnation if they fail to change "gear" properly at the point where old growth regimes reach the limit during the convergence process.

In this type of models, success of the past becomes a hurdle for the future at certain point. Acemoglu, Aghion, and Zilibotti (2006) argue that growth strategy should change from investmentbased to innovation-based strategy to avoid this trap. Basu and Weil (1998); and Aghion, Howitt, and Mayer-Foulkes (2005), respectively, emphasize that technologies and institutions should change appropriately following the level of economic development.

Unlike previous works on the "trap," this paper focuses on demographic factors as, at least temporary, important sources of the middle-income trap. It is well known that the role of demographic factors or demographic dividend has been significant in the development of Asia. Young (1995); Bloom and Williamson (1997); Bloom, Canning, and Malaney (1999); Mason and Kinugasa (2008); Deaton and Paxson (1997); Lee, Mason, and Miller (2003); Mason and Lee (2007); Lee and Mason (2010); Mason, Lee, and Lee (2010); and Lee, Mason, and Park (2012) all view that demographic transition accounts for significant parts of Asia's economic growth. This naturally leads to the possibility that Asia's growth could face adverse effects once demographic dividends turn negative, implying a stagnating force due to demographics.

$\mathrm{Ha}$ and Lee (2016) provide a framework for the analysis of a demography-driven middle-income trap. They focus on the key variable that effectively summarizes demographic structure: the support ratio or the ratio of (effective) workers to (effective) consumers. They argue that, in the early stages of development, Asia's fast demographic transition raised support ratios that created a huge demographic dividend, thereby encouraging Asia's fast convergence and economic development. However, in later stages, low fertility, which economic development brought about through the quantity-quality trade-off, eventually leads to falling support ratios and negative demographic dividend.' If the support ratio falls to a level too low for catching up with the frontier, then the economy can get into a nonconvergence trap.

As for the quantity-quality trade-off, refer to Becker (1960); Galor (2011); and Mason, Lee, and Lee (2010). 
Based on Ha and Lee (2016), we develop this concept by providing and analyzing the three conditions for the trap and the dynamic aspect of support ratios, both theoretically and empirically. We also try to evaluate the sustainability of the high support ratio of Asia with some comparison between regions and income groups.

\section{B. Three Conditions for Demography-Driven Middle-Income Trap}

We would like to suggest three conditions for a demography-driven middle-income trap.

First, demographic factors should matter for economic growth and convergence. In this paper, we look at the relationship between support ratio and growth rates. We view that support ratios can affect saving and investment rates, and eventually growth rates of GDP per capita, which determines the speed of convergence to the frontier. From the viewpoint of the NTAs, a high support ratio means that more resources can be allocated within productive generations through saving and investment.

Second, there should be a negative relationship between the level of development and fertility. As the economy develops, it needs more human capital for learning and adopting frontier technologies, leading to higher returns to education and more investment in education. More education accompanies lower fertility following the mechanism of quantity-quality trade-off.

Third, fertility is low enough to eventually lead to low support ratio. This is more complicated than other conditions, and creates more complex issues since low fertility raises support ratio in the short term, but could pull it down in the long run. Moreover, according to Lee, Mason, et al. (2014), low fertility does not always lead to long-run low suboptimal support ratios as there could be cases where the maximum steady state support ratios correspond to subreplacement fertility-less than the fertility level of 2.1. We delve into this issue later in this paper.

Our previous research ( $\mathrm{Ha}$ and Lee 2016) analyzes the first and second conditions for Asia and the world, and this paper shows the three conditions for the Asian Development Bank (ADB) economies and others, as well as for the regions in Asia. In analyzing the third condition, we model the dynamics of support ratio and use the concept of steady state support ratios. The structure of the trap and the conditions can be summarized in Figure 5.

Figure 5: Structure of Demography-Driven MiddleIncome Trap

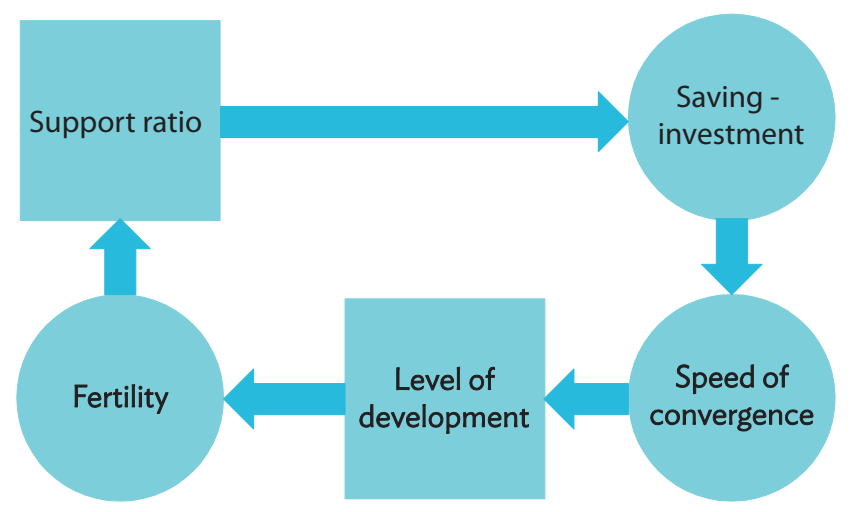

Note: Squares refer to state variables, while circles refer to control variables. Source: Authors' developed framework. 


\section{TESTING FOR CONDITIONS OF DEMOGRAPHY-DRIVEN MIDDLE-INCOME TRAP}

To test the conditions for middle-income trap, we conduct annual panel analyses using the Penn World Table (PWT) 9.0 and World Development Indicators for 178 countries among which 30 are ADB developing members for the years 1970-2014. ${ }^{2}$ We present the results for both random-effects models and fixed-effects models as the Hausman test results are ambiguous for many cases. ${ }^{3}$ We use parsimonious models to see the relationship between major variables.

\section{A. Condition (1): Support Ratio Matters for Economic Growth}

The first condition states that support ratios and economic growth should have positive relationships. In the panel analyses in this section, support ratio is defined as the population share of age 15-64, due to the coverage of data. The NTAs data are more precise, but time series and country coverage are quite limited.

Table 1: Support Ratio and Growth Rates

\begin{tabular}{|c|c|c|c|c|}
\hline & \multicolumn{2}{|c|}{ GDP per Capita Growth - ADB } & \multicolumn{2}{|c|}{ GDP per Capita Growth - Others } \\
\hline & Random Effect & Fixed Effect & Random Effect & Fixed Effect \\
\hline \multirow[t]{2}{*}{ Support ratio } & $0.1798^{* * *}$ & $0.2182^{* * *}$ & $0.0671^{* * *}$ & $0.1090^{* * *}$ \\
\hline & $(0.0292)$ & $(0.0334)$ & $(0.0114)$ & $(0.0212)$ \\
\hline \multirow[t]{2}{*}{ Constant } & $0.1192^{* * *}$ & $0.1408^{* * *}$ & $0.0550^{* * *}$ & $0.0774^{* * *}$ \\
\hline & $(0.0152)$ & $(0.0170)$ & $(0.0062)$ & $(0.0113)$ \\
\hline No. of observations & 1,160 & 1,160 & 5,850 & 5,850 \\
\hline No. of economies & 30 & 30 & 141 & 141 \\
\hline R-squared & 0.0280 & 0.0280 & 0.0071 & 0.0071 \\
\hline
\end{tabular}

$\mathrm{ADB}=$ Asian Development Bank developing member economies, GDP = gross domestic product.

Notes: All independent variables are logged. Numbers in parentheses are standard errors. ${ }^{*},{ }^{* *}$, and ${ }^{* * *}$ denote significance at the $10 \%, 5 \%$, and $1 \%$ level, respectively.

Source: Authors' calculation.

Table 1 shows the results. Here, the two variables are indeed closely related. The coefficients say that this relationship is much stronger for ADB developing member economies than for others, implying that Asian economies have utilized demographic dividend more intensively for economic growth. This was possible due to the fast decline in fertility during the early stages of demographic transition.

We also looked at the relationship between support ratio and saving/investment rates (Tables 2 and 3). All of the results show that saving/investment rates are more closely tied to support ratio in Asia. This is consistent with the literature that shows a large part of Asia's growth has been the realization of the first and second demographic dividends. The first dividend, which is the direct effect of increased labor supply among population, accounts for more than 10\% of growth in many countries

See Feenstra, Inklaar, and Timmer (2015) for details of PWT 9.0.

Number of countries and number of observations differ slightly across tables depending on the availability of data. However, this does not affect the qualitative results of the paper. 
( $\mathrm{Ha}$ and Lee 2016). But, it seems that the second dividend-increased saving and capital accumulation-is never smaller than the first dividend in Asia.

Table 2: Support Ratio and National Saving

\begin{tabular}{lrrrr}
\hline & \multicolumn{2}{c}{ National Saving - ADB } & \multicolumn{2}{c}{ National Saving - Others } \\
\cline { 2 - 5 } & \multicolumn{1}{c}{ Random Effect } & Fixed Effect & Random Effect & Fixed Effect \\
\hline Support ratio & $2.5080^{* * *}$ & $2.5042^{* * *}$ & $0.6489^{* * *}$ & $0.4432^{* * *}$ \\
& $(0.2136)$ & $(0.2151)$ & $(0.1477)$ & $(0.1533)$ \\
Constant & $-0.5832^{* * *}$ & $-0.4556^{* * *}$ & $-1.6507^{* * *}$ & $-1.6037^{* * *}$ \\
& $(0.1727)$ & $(0.1094)$ & $(0.0979)$ & $(0.0804)$ \\
No. of observations & 1,111 & 1,111 & 5,146 & 5,146 \\
No. of economies & 30 & 30 & 140 & 140 \\
R-squared & 0.1325 & 0.1325 & 0.1147 & 0.1147 \\
\hline
\end{tabular}

$\mathrm{ADB}=$ Asian Development Bank developing member economies.

Notes: All variables are logged. Numbers in parentheses are standard errors. * **, and ${ }^{* * *}$ denote significance at the 10\%, 5\%, and 1\% level, respectively.

Source: Authors' calculation.

Table 3: Support Ratio and Investment Rate

\begin{tabular}{|c|c|c|c|c|}
\hline & \multicolumn{2}{|c|}{ Investment Rate - ADB } & \multicolumn{2}{|c|}{ Investment Rate - Others } \\
\hline & Random Effect & Fixed Effect & Random Effect & Fixed Effect \\
\hline \multirow[t]{2}{*}{ Support ratio } & $2.0773^{* * *}$ & $2.0739^{* * *}$ & $1.1984^{* * *}$ & $1.1039^{* * *}$ \\
\hline & $(0.1419)$ & $(0.1431)$ & $(0.0857)$ & $(0.0896)$ \\
\hline \multirow[t]{2}{*}{ Constant } & $-0.7262^{* * *}$ & $-0.6721^{* * *}$ & $-1.0699^{* * *}$ & $-1.1160^{* * *}$ \\
\hline & $(0.1113)$ & $(0.0730)$ & $(0.0553)$ & $(0.0480)$ \\
\hline No. of observations & 1,189 & 1,189 & 5,990 & 5,990 \\
\hline No. of economies & 30 & 30 & 141 & 141 \\
\hline R-squared & 0.1569 & 0.1569 & 0.1715 & 0.1715 \\
\hline
\end{tabular}

$\mathrm{ADB}=$ Asian Development Bank developing member economies.

Notes: All variables are logged. Numbers in parentheses are standard errors. *, **, and ${ }^{* * *}$ denote significance at the 10\%, 5\%, and $1 \%$ level, respectively.

Source: Authors' calculation.

We also looked at the difference between regions in Asia. As for the effect of support ratio on saving rate, there are no big differences among regions in Asia, but the coefficients are a little high in Central Asia and a little low in Southeast Asia. The coefficient of support ratio on investment rates is summarized as follows: Central Asia shows no significance, but other regions show significant correlations, with South and Southeast Asia having high elasticity with respect to support ratios. 
These analyses show that, in general, Asia has exploited demographic dividends more intensely than others, and high and rising support ratios have been important in catching up with the frontier. Therefore, the first condition of middle-income trap is satisfied in Asia: support ratio matters more for growth in Asia (Tables 3-7).

Table 4: Support Ratio and National Saving by Subregion in Asia (1): Central and East Asia

\begin{tabular}{|c|c|c|c|c|}
\hline & \multicolumn{2}{|c|}{ National Saving - Central Asia } & \multicolumn{2}{|c|}{ National Saving - East Asia } \\
\hline & Random Effect & Fixed Effect & Random Effect & Fixed Effect \\
\hline \multirow[t]{2}{*}{ Support ratio } & $4.6038^{* * *}$ & $4.7468^{* * *}$ & $3.0057^{* * *}$ & $2.7649^{* * *}$ \\
\hline & $(0.0607)$ & $(1.0823)$ & $(0.2624)$ & $(0.2621)$ \\
\hline \multirow[t]{2}{*}{ Constant } & -0.1480 & 0.0565 & -0.0207 & -0.1152 \\
\hline & $(0.5795)$ & $(0.5018)$ & $(0.1299)$ & $(0.1113)$ \\
\hline No. of observations & 153 & 153 & 267 & 267 \\
\hline No. of economies & 8 & 8 & 6 & 6 \\
\hline R-squared & 0.0444 & 0.0444 & 0.4966 & 0.4966 \\
\hline
\end{tabular}

Notes: All variables are logged. Numbers in parentheses are standard errors. ${ }^{*},{ }^{* *}$, and ${ }^{* * *}$ denote significance at the $10 \%, 5 \%$, and $1 \%$ level, respectively.

Source: Authors' calculation,

Table 5: Support Ratio and National Saving by Subregion in Asia (2): South and Southeast Asia

\begin{tabular}{|c|c|c|c|c|}
\hline & \multicolumn{2}{|c|}{ National Saving - South Asia } & \multicolumn{2}{|c|}{ National Saving -Southeast Asia } \\
\hline & Random Effect & Fixed Effect & Random Effect & Fixed Effect \\
\hline \multirow[t]{2}{*}{ Support ratio } & $2.8906^{* * *}$ & $2.9168^{* * *}$ & $2.1594^{* * *}$ & $2.1059^{* * *}$ \\
\hline & $(0.4418)$ & $(0.4434)$ & $(0.3018)$ & $(0.3025)$ \\
\hline \multirow[t]{2}{*}{ Constant } & -0.2700 & -0.2479 & $-0.5169^{* *}$ & $-0.5044^{* * *}$ \\
\hline & $(0.3644)$ & $(0.5018)$ & $(0.2573)$ & $(0.1554)$ \\
\hline No. of observations & 310 & 310 & 431 & 431 \\
\hline No. of economies & 7 & 7 & 10 & 10 \\
\hline R-squared & 0.0198 & 0.0198 & 0.2373 & 0.2373 \\
\hline
\end{tabular}

Notes: All variables are logged. Numbers in parentheses are standard errors. ${ }^{*}{ }^{* *}$, and ${ }^{* * *}$ denote significance at the $10 \%, 5 \%$, and $1 \%$ level, respectively.

Source: Authors' calculation. 
Table 6: Support Ratio and Investment Rate by Subregion in Asia (1): Central and East Asia

\begin{tabular}{|c|c|c|c|c|}
\hline & \multicolumn{2}{|c|}{ Investment Rate - Central Asia } & \multicolumn{2}{|c|}{ Investment Rate - East Asia } \\
\hline & Random Effect & Fixed Effect & Random Effect & Fixed Effect \\
\hline \multirow[t]{2}{*}{ Support ratio } & 0.4631 & 0.2756 & $0.6803^{* * *}$ & $0.7318^{* * *}$ \\
\hline & $(0.5955)$ & $(0.6098)$ & $(0.2083)$ & $(0.2122)$ \\
\hline \multirow[t]{2}{*}{ Constant } & $-1.9028^{* * *}$ & $-1.9911^{* * *}$ & $-1.0090^{* * *}$ & $-0.9874^{* * *}$ \\
\hline & $(0.3174)$ & $(0.2870)$ & $(0.1089)$ & $(0.0906)$ \\
\hline No. of observations & 199 & 199 & 270 & 270 \\
\hline No. of economies & 8 & 8 & 6 & 6 \\
\hline R-squared & 0.0731 & 0.0731 & 0.0079 & 0.0079 \\
\hline
\end{tabular}

Notes: All variables are logged. Numbers in parentheses are standard errors. *, **, and ${ }^{* * *}$ denote significance at the 10\%, 5\%, and 1\% level, respectively.

Source: Authors' calculation.

Table 7: Support Ratio and Investment Rate by Subregion in Asia (2): South and Southeast Asia

\begin{tabular}{|c|c|c|c|c|}
\hline & \multicolumn{2}{|c|}{ Investment Rate - South Asia } & \multicolumn{2}{|c|}{ Investment Rate -Southeast Asia } \\
\hline & Random Effect & Fixed Effect & Random Effect & Fixed Effect \\
\hline \multirow[t]{2}{*}{ Support ratio } & $2.9056^{* * *}$ & $2.9064^{* * *}$ & $2.7087^{* * *}$ & $2.6933^{* * *}$ \\
\hline & $(0.2963)$ & $(0.2980)$ & $(0.1959)$ & $(0.1969)$ \\
\hline \multirow[t]{2}{*}{ Constant } & -0.1606 & -0.1602 & $-0.2974^{*}$ & $-0.3053^{* * *}$ \\
\hline & $(0.2271)$ & $(0.1676)$ & $(0.1710)$ & $(0.1018)$ \\
\hline No. of observations & 315 & 315 & 450 & 450 \\
\hline No. of economies & 7 & 7 & 10 & 10 \\
\hline R-squared & 0.1843 & 0.1843 & 0.3224 & 0.3224 \\
\hline
\end{tabular}

Notes: All variables are logged. Numbers in parentheses are standard errors. *, **, and ${ }^{* * *}$ denote significance at the 10\%, 5\%, and 1\% level, respectively.

Source: Authors' calculation.

\section{B. Condition (2): Development Causing Low Fertility-Quantity-Quality Trade-Off}

The second condition is about the relationship between the level of development and fertility. This issue has been discussed widely within the framework of "quantity-quality trade-off" where increased investment in human capital accompanies lower fertility following households' optimization of decision making. As an economy develops and moves closer to the frontier, more human capital is needed to learn and adopt the frontier technologies, and the return to human capital could rise. This makes households put more weight on the quality rather than the number of children.

Table 8 shows that fertility is very sensitive to the level of economic development in Asia, measured by either GDP per capita or the level of average human capital a la PWT 9.0. If we look at the differences across regions in Asia, human capital accumulation has larger adverse effects on 
fertility, especially in East and Southeast Asia (Tables 9 and 10). On the other hand, in Central Asia, fertility is not so sensitive to economic development. Table 11 shows that, for all income groups, human capital accumulation has a strong negative effect on fertility. ${ }^{4}$

Fertility seems to be more sensitive to economic development in Asia than in other continents. There may be various reasons: Asia's education is much costlier due to factors like the high cost of learning the English language or tough competition due to education's role of screening better workers. Moreover, despite the high cost, the massive increase in human capital needed during the process of economic catch-up has inevitably brought about the rapid decline in fertility in Asia.

Table 8: Gross Domestic Product per Capita, Level of Human Capital, and Fertility

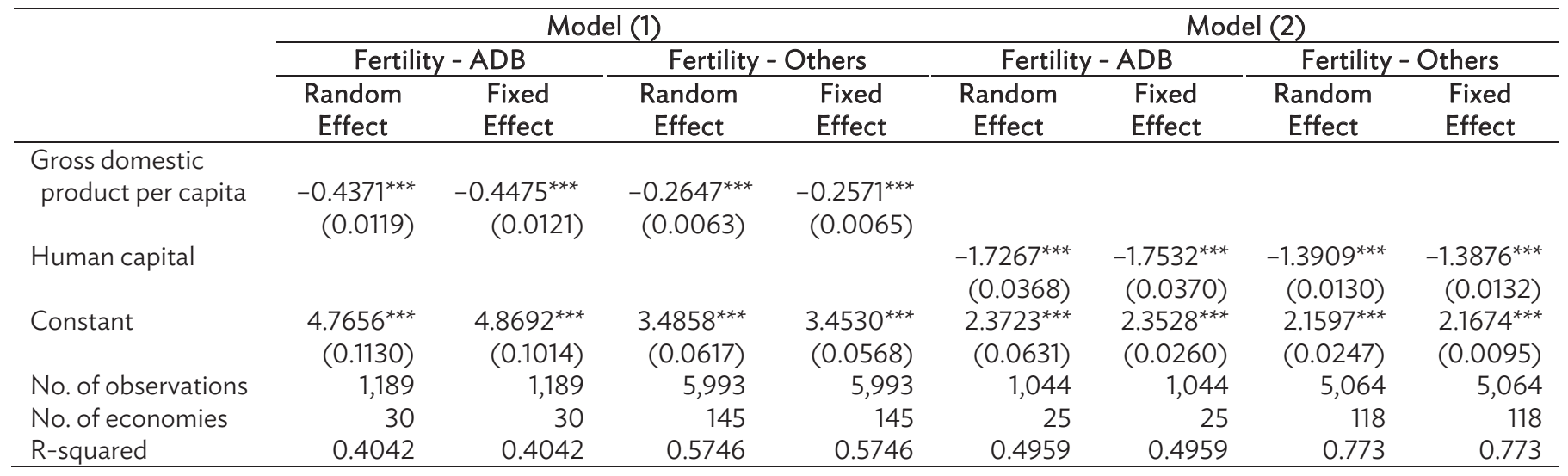

$\mathrm{ADB}=$ Asian Development Bank developing member economies.

Notes: All variables are logged. Numbers in parentheses are standard errors. ${ }^{*}{ }^{* *}$, and ${ }^{* * *}$ denote significance at the $10 \%, 5 \%$, and $1 \%$ level, respectively.

Source: Authors' calculation.

\section{Table 9: Gross Domestic Product per Capita, Level of Human Capital, and Fertility by Region in Asia (Model 1)}

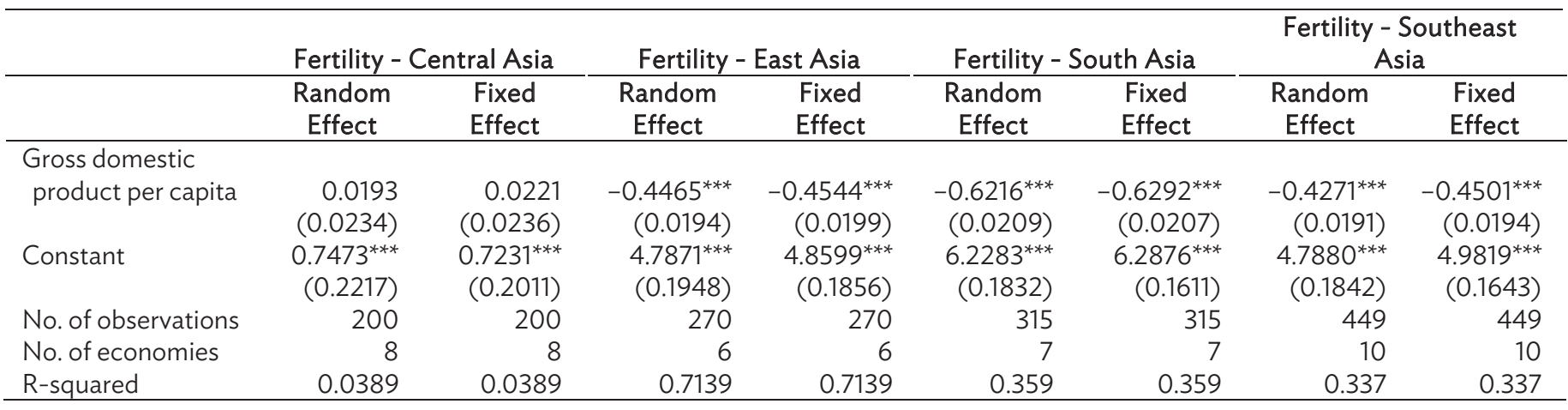

Notes: All variables are logged. Numbers in parentheses are standard errors. *, **, and *** denote significance at the 10\%, 5\%, and 1\% level, respectively. Source: Authors' calculation.

4 We follow ADB's classification of income groups: in 2011 purchasing power parity (PPP), using PWT 9.0; extremely low-income countries: GDP per capita (2011 PPP) $\leq \$ 1,096$; low-income countries: \$1,096 < GDP per capita (2011 PPP) $\leq \$ 2,585$; lower-middleincome countries: $\$ 2,585<$ GDP per capita (2011 PPP) $\leq \$ 5,351$; upper-middle-income countries: $\$ 5,351<$ GDP per capita (2011 PPP) $\leq$ $\$ 17,600$; high-income countries: GDP per capita (2011 PPP) > \$17,600. 


\section{Table 10: Gross Domestic Product per Capita, Level of Human Capital, and Fertility by Subregion in Asia (Model 2)}

\begin{tabular}{|c|c|c|c|c|c|c|c|c|}
\hline & \multicolumn{2}{|c|}{ Fertility-Central Asia } & \multicolumn{2}{|c|}{ Fertility - East Asia } & \multicolumn{2}{|c|}{ Fertility - South Asia } & \multicolumn{2}{|c|}{$\begin{array}{c}\text { Fertility - Southeast } \\
\text { Asia }\end{array}$} \\
\hline & $\begin{array}{l}\text { Random } \\
\text { Effect }\end{array}$ & $\begin{array}{l}\text { Fixed } \\
\text { Effect }\end{array}$ & $\begin{array}{l}\text { Random } \\
\text { Effect }\end{array}$ & $\begin{array}{l}\text { Fixed } \\
\text { Effect }\end{array}$ & $\begin{array}{c}\text { Random } \\
\text { Effect }\end{array}$ & $\begin{array}{l}\text { Fixed } \\
\text { Effect }\end{array}$ & $\begin{array}{l}\text { Random } \\
\text { Effect }\end{array}$ & $\begin{array}{l}\text { Fixed } \\
\text { Effect }\end{array}$ \\
\hline Human capital & $\begin{array}{r}-0.5206^{* *} \\
(0.2526)\end{array}$ & $\begin{array}{l}-0.5211^{* *} \\
(0.2540)\end{array}$ & $\begin{array}{r}-2.2270^{* * *} \\
(0.0639)\end{array}$ & $\begin{array}{r}-2.2348^{* * *} \\
(0.0638)\end{array}$ & $\begin{array}{r}-1.4999^{* * *} \\
(0.0952)\end{array}$ & $\begin{array}{r}-1.5962^{* * *} \\
(0.1007)\end{array}$ & $\begin{array}{r}-1.6489^{* * *} \\
(0.0432)\end{array}$ & $\begin{array}{r}-1.6539^{* * *} \\
(0.0433)\end{array}$ \\
\hline Constant & $\begin{array}{r}1.5429 \\
(0.3452)\end{array}$ & $\begin{array}{r}1.5434 \\
(0.2817)\end{array}$ & $\begin{array}{r}2.6328^{* * *} \\
(0.1783)\end{array}$ & $\begin{array}{l}2.6398^{* * *} \\
(0.0578)\end{array}$ & $\begin{array}{l}2.1218^{* * *} \\
(0.0724)\end{array}$ & $\begin{array}{l}2.1684^{* * *} \\
(0.0508)\end{array}$ & $\begin{array}{l}2.2248^{* * *} \\
(0.0955)\end{array}$ & $\begin{array}{r}2.2289^{* * *} \\
(0.0283)\end{array}$ \\
\hline $\begin{array}{l}\text { No. of } \\
\text { observations }\end{array}$ & 100 & 100 & 270 & 270 & 270 & 270 & 449 & 449 \\
\hline No. of economies & 4 & 4 & 6 & 6 & 6 & 6 & 10 & 10 \\
\hline R-squared & 0.0059 & 0.0059 & 0.3036 & 0.3036 & 0.4964 & 0.4964 & 0.5056 & 0.5056 \\
\hline
\end{tabular}

Notes: All variables are logged. Numbers in parentheses are standard errors. ${ }^{*},{ }^{* *}$, and ${ }^{* *}$ denote significance at the $10 \%, 5 \%$, and $1 \%$ level, respectively.

Source: Authors' calculation.

Table 11: Elasticity of Fertility with Respect to Level of Development by Income Group

\begin{tabular}{lccccc}
\hline & \multicolumn{2}{c}{ GDP per Capita and Fertility - ADB } & \multicolumn{2}{c}{ Human Capital and Fertility - ADB } \\
\cline { 2 - 3 } & \multicolumn{2}{c}{ Random Effect } & Fixed Effect & Random Effect & Fixed Effect \\
\hline Extremely low income & $-0.7096^{* * *}$ & $-0.7285^{* * *}$ & $-1.5503^{* * *}$ & $-1.6297^{* * *}$ \\
Low income & $-0.8303^{* * *}$ & $-0.8340^{* * *}$ & $-2.0877^{* * *}$ & $-2.1770^{* * *}$ \\
Lower-middle income & $-0.4689^{* * *}$ & $-0.4721^{* * *}$ & $-1.4598^{* * *}$ & $-1.4888^{* * *}$ \\
Upper-middle income & $-0.3264^{* * *}$ & $-0.3254^{* * *}$ & $-1.1153^{* * *}$ & $-1.1694^{* * *}$ \\
High income & 0.0349 & 0.0320 & $-1.6825^{* * *}$ & $-1.6847^{* * *}$ \\
\hline
\end{tabular}

$\mathrm{ADB}=$ Asian Development Bank developing member economies.

Notes: Right two columns and left two columns are the results of separate regressions. All variables are logged. * ${ }^{* *}$, and ${ }^{* * *}$ denote significance at the $10 \%, 5 \%$, and $1 \%$ level, respectively.

Source: Authors' calculation.

\section{Condition (3): Low Fertility Leading to Too Low Support Ratio for Catch-Up}

According to Lee, Mason, et al. (2014) low fertility does not necessarily mean low support ratio in the long run. To put it simply, there can be a long-run optimal fertility that can maximize support ratio. One can easily conjecture that extremely high long-run fertility will lead to low support ratio due to too many children for each household, whereas extremely low long-run fertility will cause low support ratio due to the ever-shrinking size of workers compared with retired generations. Moreover, the optimal fertility that maximizes support ratio has nothing to do with the replacement level of fertility, meaning that the everincreasing or ever-decreasing population size could be optimal to keep support ratio high. Hence, it is possible that relatively high or low fertility can last for quite a long time. Recall that an average household can choose too low or too high fertility to maximize its within-household support ratio. 
Considering these issues, the condition that low fertility leads to too low support ratio for catchup is more complicated than it seems. Fertility affects support ratio with time lag and complex dynamics. To analyze this problem, we set up a model based on $\mathrm{Ha}$ and Lee (2015), and extend it to show the relationship between fertility and steady state support ratio. Then, we put actual numbers to compare current support ratio with the steady state support ratio, which enables us to evaluate sustainability of high support ratio. This analysis is important because, if high support ratios due to low fertility in recent years correspond to a very low support ratio in the long run, then the high support ratio cannot be sustained in the future. In other words, if fertility decline raises support ratio in the short run but lowers it in the long run, then the speed of convergence or catch-up will erode, leading to a trap.

Therefore, we need to evaluate the sustainability of current support ratio for each country to see whether the country will face decline in support ratio. We do this by utilizing a model for the dynamics of support ratio presented by $\mathrm{Ha}$ and Lee (2015). In the model, the key state variables are the current support ratio ( $I)$, and the steady state support ratio $\left(I_{s s}\right)$, the latter of which is the steady state value of support ratio that is implied by current birth-death rate combinations. The dynamics are as follows.

The support ratio $l$ is:

$$
l=L / N
$$

where $L$ is working-age (age 15-64) population and $N$ is total population.

The law of motion of support ratio is simply:

$$
\frac{i}{l}=\frac{\dot{L}}{L}-\frac{\dot{N}}{N}
$$

And, the motion of working-age population $L$ is:

$$
\dot{L}=z N-(m+d) L
$$

where $z$ is the labor force inflow rate, which is the flow of population into the labor force as a ratio of population, $m$ is retirement rate of $L$, and $d$ is mortality rate of $L$.

Then, the motion of $N$ is:

$$
\dot{N}=n N
$$

Putting (3) and (4) in (2), we have:

$$
\frac{\dot{l}}{l}=\frac{\dot{L}}{L}-\frac{\dot{N}}{N}=\frac{z N}{L}-(m+d)-n=\frac{z}{l}-(m+d)-n
$$

Letting (5) equal to zero, the steady state value of $l$ is obtained as follows.

$$
l_{s s}=\frac{z}{m+d+n}
$$

This is consistent with the findings of Lee, Mason, et al. (2014) where l is constant, but population growth rate is either positive or negative. 
Now, we would like to apply this concept to Asian countries. In doing so, we introduce several simplifying assumptions: (i) labor force inflow is the same as the number of people born 15 years ago; (ii) L survives until 64, if life expectancy is greater than 64; and (iii) labor force outflow is the number of people born 64 years ago, if life expectancy is greater than 64. Otherwise, labor force outflow is mortality rate multiplied by population. Then, we have the following formula:

$$
l_{S S}=\left\{\begin{array}{c}
\frac{b\left\{(1+n)^{-15}-(1+n)^{-64}\right\}}{n}, \text { if life expectancy }>64 \\
\frac{b(1+n)^{-15}-(b-n)}{n}, \text { if life expectancy } \leq 64
\end{array}\right.
$$

We define $\operatorname{diffsr}=l-l_{s s}$, which converges to zero in the long run. Then, we have the following proposition.

Proposition: As the absolute value of diffsr becomes larger, the speed and magnitude of support ratio adjustment becomes larger during the process of convergence to the steady state, as long as the current values of birth-death rates persist.

This is because diffsr measures the amount of transitional factors and, therefore, the need for adjustment in the future. Figure 6 shows the relationship between current support ratio and the steady state support ratio. What is interesting here is that the two variables have an inverse- $U$ relationship, implying that too low or too high support ratios are not sustainable. Also, it seems that high support ratios that exceed 0.65 cannot be sustained if current birth-death rates do not change drastically. In the case of Asia, many middle-income countries now already reached 0.7 or above.

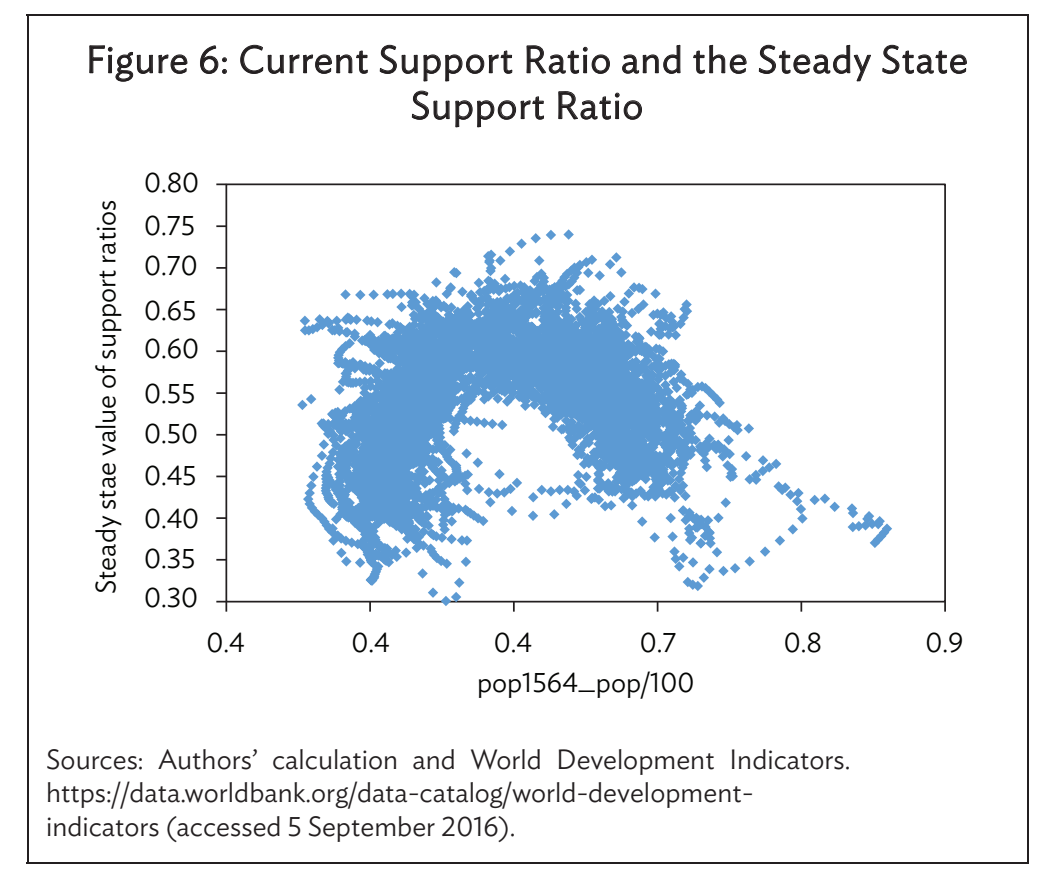

In Figure 7, we present the trends in the two support ratios for selected countries, where the gaps are quite large. The Republic of Korea and the PRC have exceptionally large gaps, predicting large long-run adjustments of support ratios. Japan and Germany seem to show a little bit of adjustment, while the United States and India show relatively smaller gaps and the possibility of less drastic 
adjustments. However, except for India, the size of the gap-more than 10\%-is substantial in every aspect, and requires close attention when predicting future growth paths.

Likewise, Figure 8 shows the trends in the size of the needs for adjustment for ADB developing member economies. In a number of economies, the gap is quite small, but countries like Armenia; Azerbaijan; Brunei Darussalam; Bhutan; the PRC; Hong Kong, China; the Republic of Korea; Sri Lanka; Maldives; Malaysia; Singapore; Thailand; and Viet Nam have the support ratio gap greater than 10 percentage points. These are 13 countries out of 30. Moreover, Bangladesh, Georgia, Indonesia, Mongolia, and Uzbekistan have the gap higher than 7 percentage points. This means about two-thirds of Asian economies are facing serious headwinds of declining support ratio in the near future.

Figure 7: Gap between Actual and Steady State Support Ratios for Selected Countries
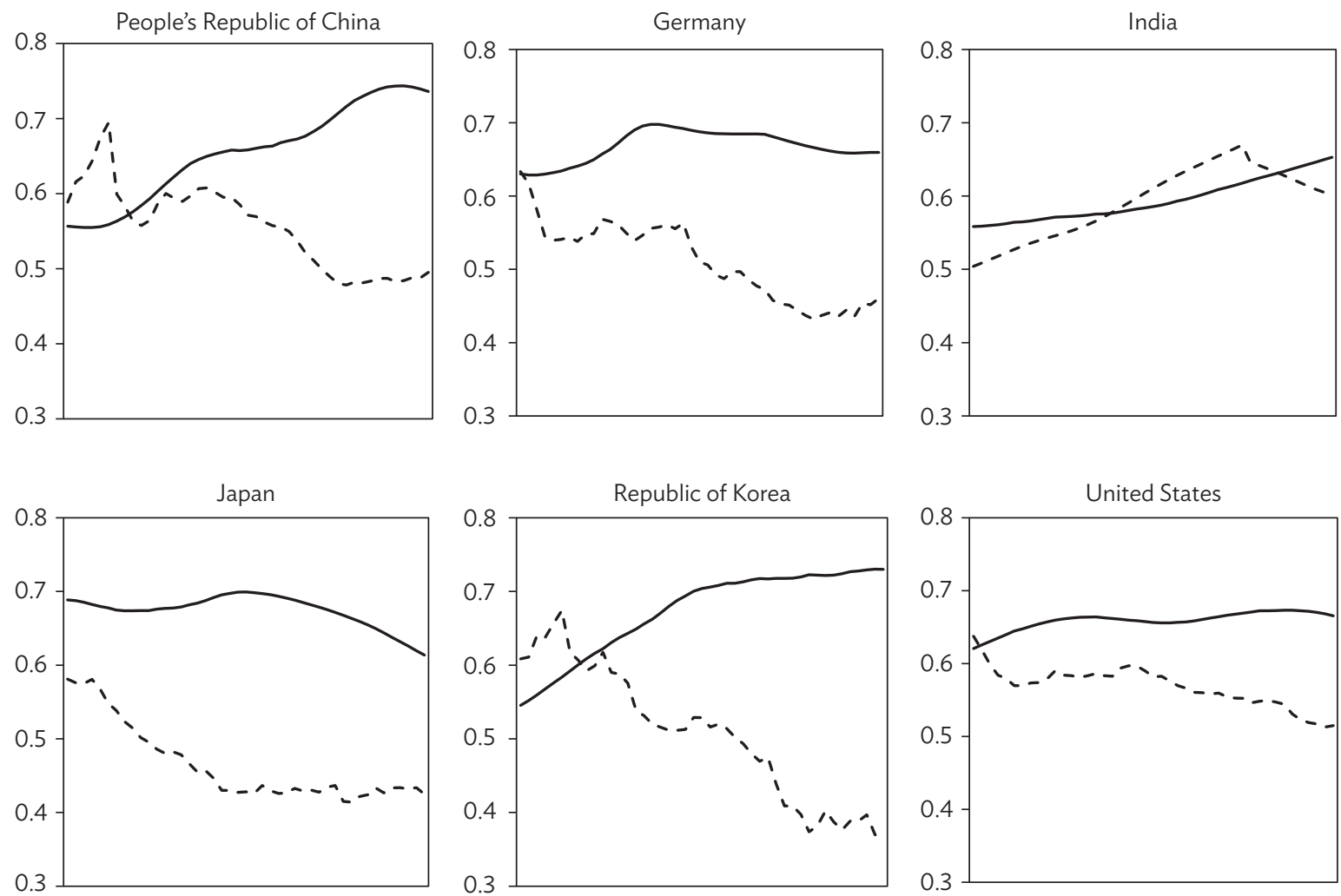

— pop1564_pop/100 ----Steady state value of support ratios

Sources: Authors' calculation and World Development Indicators. https://data.worldbank.org/data-catalog/world-development-indicators (accessed 5 September 2016).

\section{Evaluating the Possibility of a Middle-Income Trap in Asia}

As we have seen in this section, most economies in East, South, and Southeast Asia meet the three conditions of the middle-income trap driven by demographic factors. Specifically, economies with low steady state support ratios and middle income are quite likely to get into the trap, if they do not get into the high-income group quickly or fail to raise fertility. It seems that the PRC and Thailand are facing this possibility. Japan; the Republic of Korea; Hong Kong, China; and Singapore are also facing a similar trap although they are classified into the high-income category (Figure 9). 
Figure 8: Support Ratio and Its Steady State Value: ADB Regional Member Economies and Macau, China
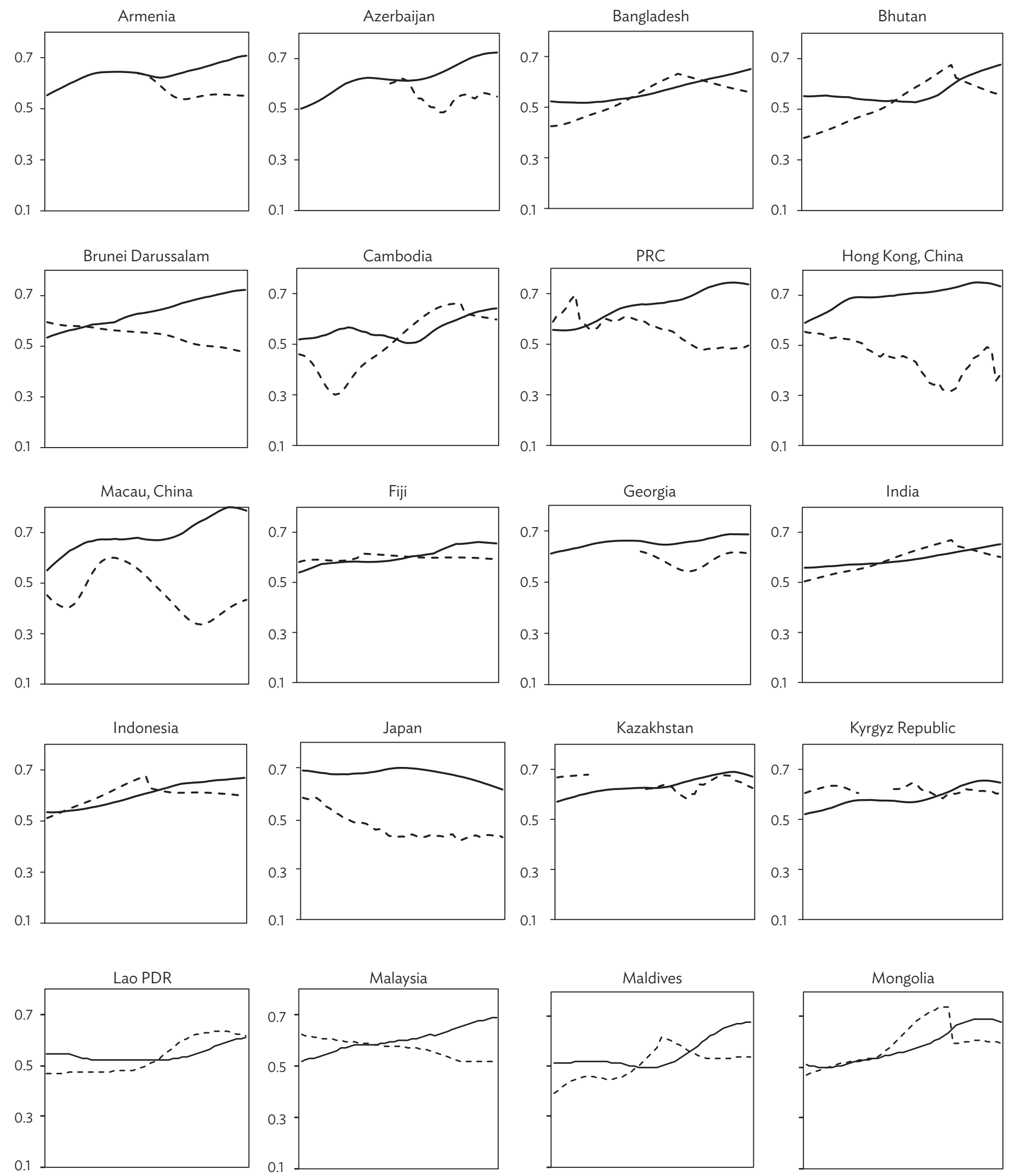
Figure 8 continued

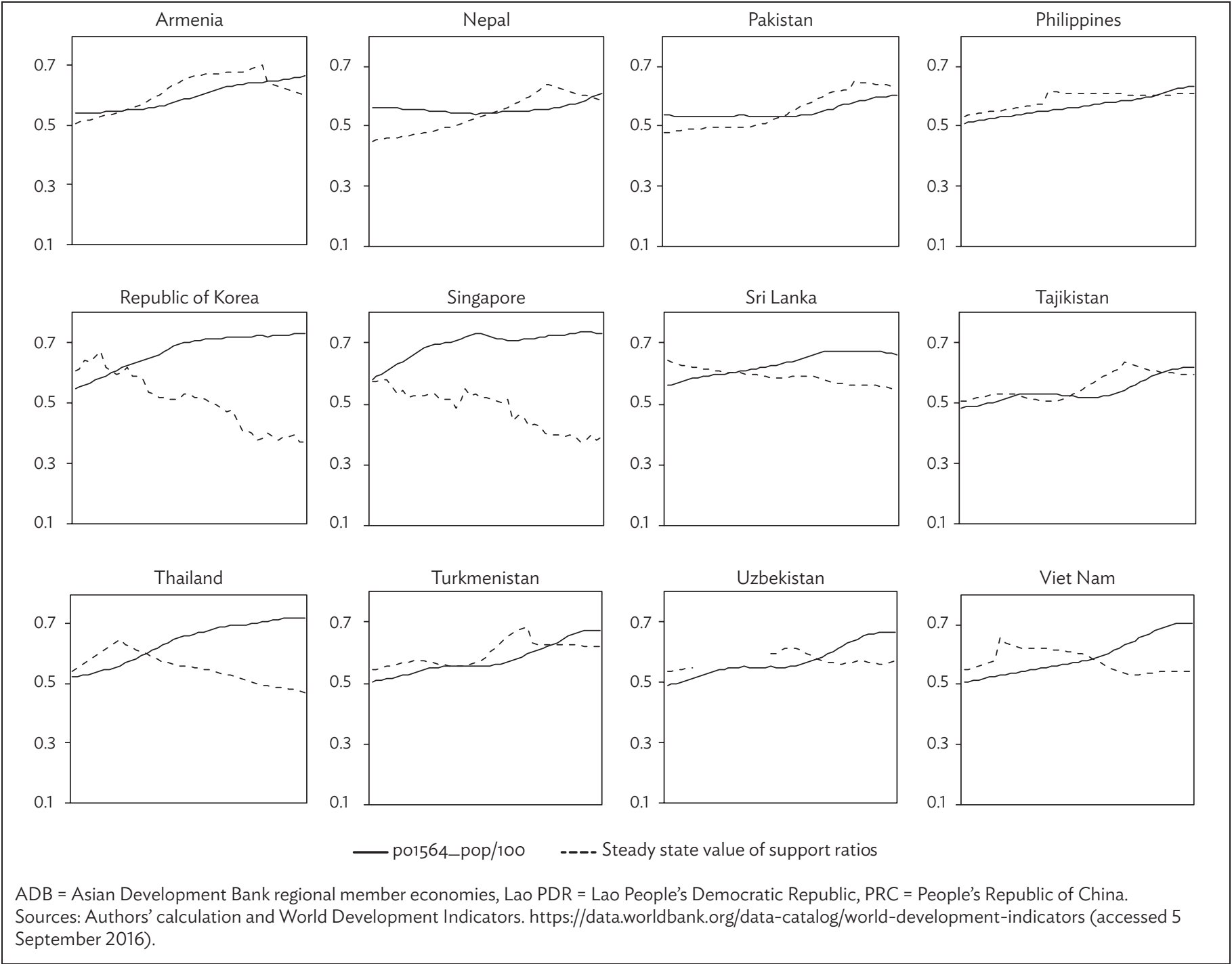

\section{E. Effects of Extending Retirement Age}

So far, steady state support ratios have been entirely determined by birth-death dynamics, given the fixed retirement age of 65 . However, one can consider extending this retirement age to make the size of the working-age population larger and the size of retirees smaller. This can be analyzed by modifying equation (7) as follows:

$$
l_{s S}=\left\{\begin{array}{c}
\frac{b\left\{(1+n)^{-15}-(1+n)^{-69}\right\}}{n}, \text { if life expectancy }>69 \\
\frac{b(1+n)^{-15}-(b-n)}{n}, \text { if life expectancy } \leq 69
\end{array}\right.
$$


Here, the only difference is that the retirement age is now 70 instead of 65 , and equation (8) gives us the new steady state support ratios for given birth-death rates. In most cases, this change raises steady state support ratios substantially. Table 12 shows that, if the retirement age is extended to 70, steady state support ratios increase by 3.45 percentage points in the Republic of Korea, 4.38 percentage points in the PRC, and 4.45 percentage points in Thailand. This narrows the gap between actual and steady state support ratios by $10 \%-18 \%$ for these countries.

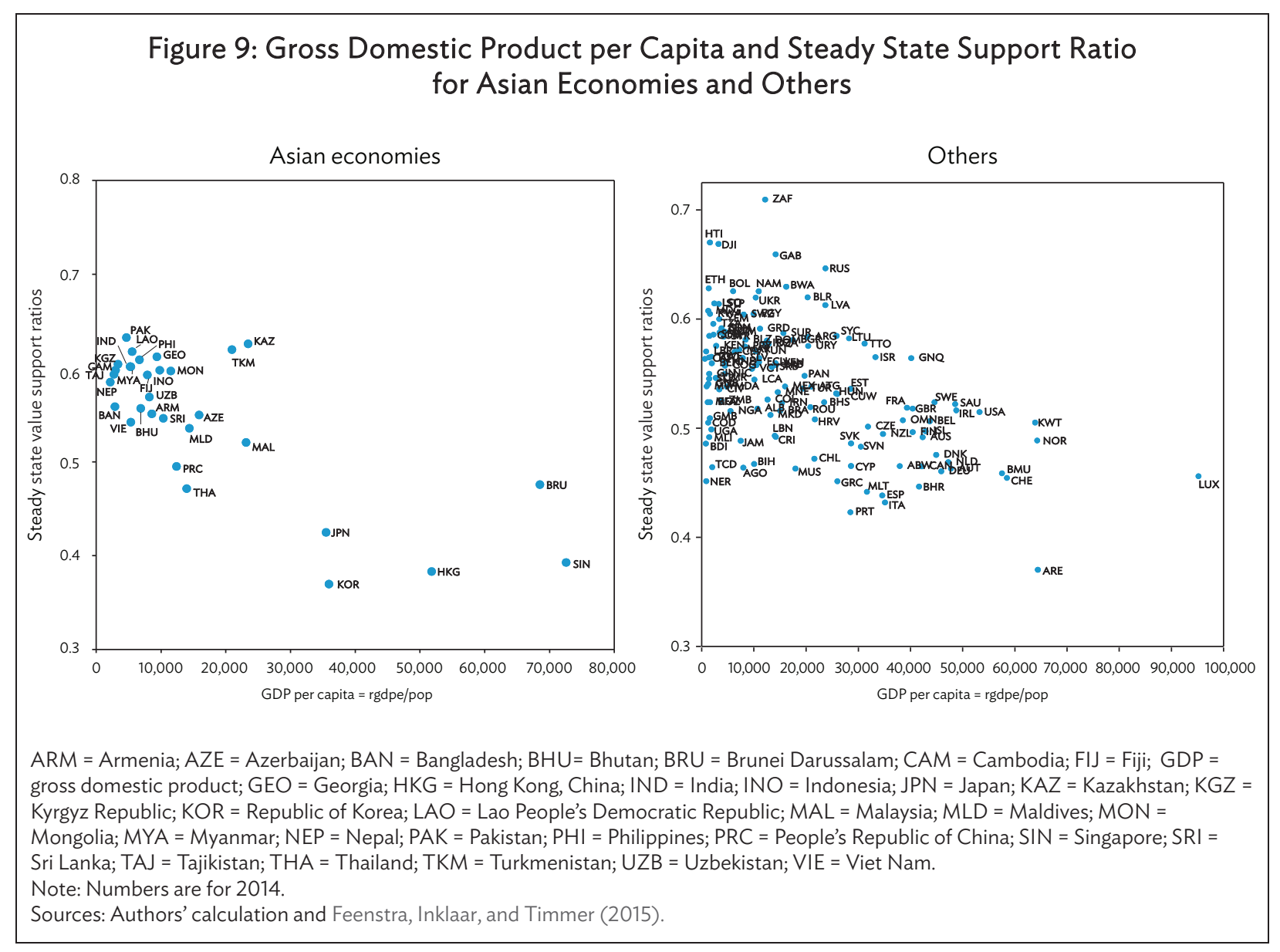

Therefore, an extended retirement age could certainly relieve the aging problems in Asia. However, one should keep in mind that this has only partial effect, and cannot change the whole direction of aging dynamics as long as there exists retirement itself. ${ }^{5}$

\footnotetext{
5 This means that if there is no retirement in the first place, age structure would not matter that much.
} 
18 | ADB Economics Working Paper Series No. 536

Table 12: Steady State Support Ratios for Retirement Age 65 and 70 for Asia

(\%)

\begin{tabular}{|c|c|c|c|c|c|}
\hline \multirow[b]{2}{*}{ Economy } & \multicolumn{3}{|c|}{ Support Ratios } & \multirow[b]{2}{*}{$(A)-(B)$} & \multirow[b]{2}{*}{$(C)-(A)$} \\
\hline & $\begin{array}{c}\text { Actual } \\
(2014)(A)\end{array}$ & $\begin{array}{l}\text { Steady-State } \\
\text { (Retirement } \\
\text { Age }=65)(B)\end{array}$ & $\begin{array}{l}\text { Steady-State } \\
\text { (Retirement } \\
\text { Age=70)(C) }\end{array}$ & & \\
\hline Armenia & 70.76 & 55.11 & 60.16 & 15.64 & 5.05 \\
\hline Azerbaijan & 72.40 & 55.00 & 59.00 & 17.40 & 4.00 \\
\hline Bangladesh & 65.07 & 55.89 & 59.69 & 9.18 & 3.80 \\
\hline Brunei Darussalam & 72.30 & 47.59 & 50.95 & 24.71 & 3.37 \\
\hline Bhutan & 67.61 & 55.71 & 59.83 & 11.90 & 4.12 \\
\hline People's Republic of China & 73.61 & 49.51 & 53.89 & 24.10 & 4.38 \\
\hline Fiji & 65.57 & 59.26 & 63.44 & 6.30 & 4.18 \\
\hline Georgia & 68.67 & 61.20 & 67.11 & 7.47 & 5.91 \\
\hline Hong Kong, China & 73.58 & 38.31 & 41.97 & 35.27 & 3.66 \\
\hline Indonesia & 66.91 & 59.76 & 72.92 & 7.15 & 13.16 \\
\hline India & 65.30 & 60.15 & 72.89 & 5.15 & 12.74 \\
\hline Japan & 61.36 & 42.49 & 47.06 & 18.87 & 4.57 \\
\hline Kazakhstan & 67.14 & 62.58 & 66.69 & 4.55 & 4.11 \\
\hline Kyrgyz Republic & 64.72 & 60.41 & 63.72 & 4.31 & 3.31 \\
\hline Cambodia & 64.18 & 59.77 & 68.54 & 4.41 & 8.77 \\
\hline Republic of Korea & 73.01 & 36.98 & 40.43 & 36.03 & 3.45 \\
\hline Lao PDR & 61.12 & 61.75 & 65.71 & -0.62 & 3.96 \\
\hline Sri Lanka & 66.30 & 54.65 & 58.97 & 11.66 & 4.32 \\
\hline Macau, China & 78.67 & 43.36 & 47.04 & 35.31 & 3.68 \\
\hline Maldives & 67.69 & 53.59 & 56.92 & 14.11 & 3.33 \\
\hline Myanmar & 66.70 & 60.14 & 75.27 & 6.56 & 15.13 \\
\hline Mongolia & 68.12 & 59.68 & 63.35 & 8.43 & 3.66 \\
\hline Malaysia & 68.96 & 52.06 & 55.87 & 16.89 & 3.81 \\
\hline Nepal & 61.10 & 58.50 & 62.51 & 2.60 & 4.01 \\
\hline Pakistan & 60.32 & 63.25 & 62.93 & -2.93 & -0.32 \\
\hline Philippines & 63.28 & 60.89 & 69.00 & 2.39 & 8.12 \\
\hline Singapore & 73.07 & 39.28 & 42.77 & 33.79 & 3.48 \\
\hline Thailand & 71.95 & 47.15 & 51.50 & 24.80 & 4.45 \\
\hline Tajikistan & 62.02 & 59.33 & 62.26 & 2.69 & 2.93 \\
\hline Turkmenistan & 67.49 & 61.97 & 71.48 & 5.52 & 9.51 \\
\hline Uzbekistan & 66.85 & 56.91 & 69.70 & 9.94 & 12.79 \\
\hline Viet Nam & 70.27 & 54.23 & 58.26 & 16.04 & 4.03 \\
\hline
\end{tabular}

Asia $=$ Asian Development Bank regional member economies and Macau, China; Lao PDR = Lao People's Democratic Republic. Note: The steady state numbers are computed using birth-death rates of 2014.

Source: Authors' calculation. 


\section{WHAT NATIONAL TRANSFER ACCOUNTS TELL ABOUT DEMOGRAPHY-DRIVEN MIDDLE-INCOME TRAP}

In this section, we will consider what NTAs tell about demography-driven middle-income trap. It is obvious that the NTAs data are much more precise for the analyses in this paper. However, the NTAs data are not yet accumulated enough for panel analyses, and only 15 Asian economies are covered in the NTAs data sheet of 2016. But, it still tells us something.

First, NTAs show a more detailed and clearer picture for quantity-quality trade-off. NTAs show that intergenerational resource allocation affects fertility and the future course of economic development. One can see a stronger and clearer relationship between human capital investment and fertility through the lens of NTAs. In particular, "human capital spending" and "consumption by age group 0-24" have strong negative correlations with fertility (Table 13). In Figure 10, human capital spending and transfer to young generation data from NTAs have a much clearer negative relationship with fertility than PWT 9.0 data. Table 12 also shows this with the NTAs human capital investment data having stronger correlation with fertility.

Second, NTAs show the transitional path of support ratios more accurately. The adverse effect of declining support ratios can last for decades, implying the possibility of a middle-income trap for several decades. Future changes in support ratios imply that transitional effects can last for decades, leading to a "temporary" trap. Figure 11 shows that, for the years between 2015-2035, some countries have positive growth rates of support ratio, meaning positive support ratios, while others have negative rates. ${ }^{6}$ But, for 2015-2055, more countries fall into the area of negative demographic dividends. The calculation of the model shows that, in the long run, with the current birth-death rates, most countries, except the Lao People's Democratic Republic, face demographic headwinds.

Figure 10: Fertility and Human Capital (left, PWT 9.0); Human Capital Spending (middle, NTAs); and Consumption by Age 0-24 (right, NTAs)
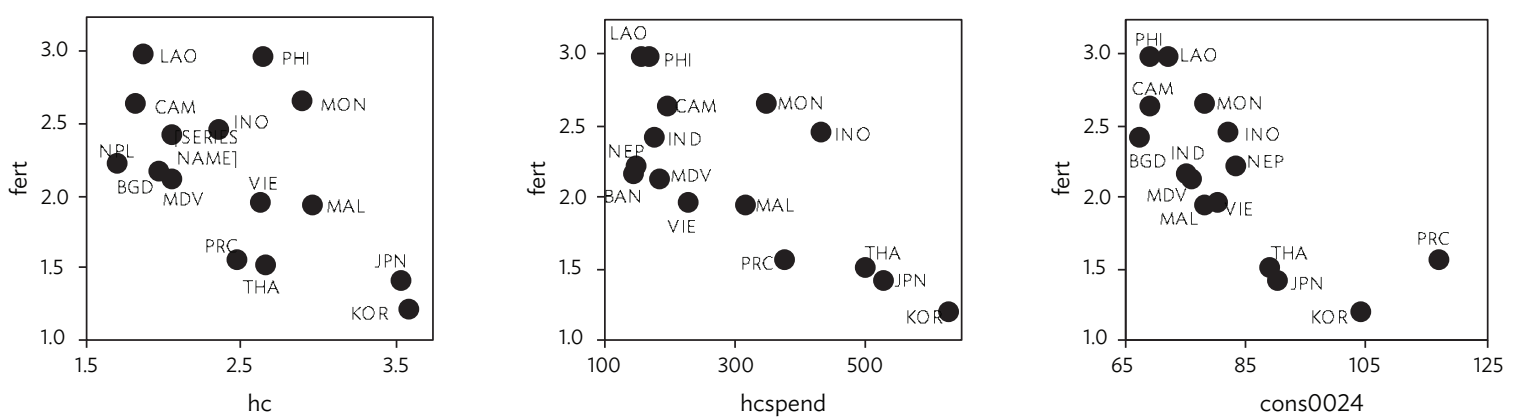

BAN = Bangladesh, CAM = Cambodia, IND = India, INO = Indonesia, JPN = Japan, $K O R=$ Republic of Korea, LAO = Lao People's Democratic Republic, $M A L=$ Malaysia,$M L D=$ Maldives,$M O N=$ Mongolia, NEP = Nepal, NTAs = national transfer accounts, PHI = Philippines, PRC = People's Republic of China, PWT = Penn World Table, THA = Thailand, VIE = Viet Nam. Sources: National Transfer Accounts; Feenstra, Inklaar, and Timmer (2015); World Development Indicators. https://data.worldbank.org/data-catalog/world-development-indicators (accessed 5 September 2016).

6 The prediction of support ratios in the NTAs data sheet 2016 uses the United Nations fertility forecast and the current intergenerational resource allocation structure. 
Table 13: Correlation between Major Variables from National Transfer Accounts and Others

\begin{tabular}{|c|c|c|c|c|c|}
\hline & Fertility & $\begin{array}{l}\text { Support Ratio } \\
2015 \text { (NTAs) }\end{array}$ & $\begin{array}{l}\text { Support Ratio } \\
2035 \text { (NTAs) }\end{array}$ & $\begin{array}{l}\text { Support Ratio } \\
2055 \text { (NTAs) }\end{array}$ & $\begin{array}{c}\text { Steady State } \\
\text { Support Ratio }\end{array}$ \\
\hline Human capital (PWT 9.0) & -0.5979 & -0.2599 & -0.7369 & -0.7162 & -0.7494 \\
\hline $\begin{array}{l}\text { Human capital spending } \\
\text { (NTAs) } \\
\text { Consumption of age 0-24 } \\
\text { (NTAs) }\end{array}$ & $\begin{array}{l}-0.7284 \\
-0.7732\end{array}$ & -0.0725 & $\begin{array}{l}-0.5453 \\
-0.7563\end{array}$ & -0.6664 & $\begin{array}{l}-0.8076 \\
-0.7296\end{array}$ \\
\hline
\end{tabular}

NTAs = national transfer accounts, PWT = Penn World Table.

Note: Number of observations is 15 . Human capital and fertility are for 2014 , while others are for various years as measured in the NTAs data sheet 2016.

Source: Authors' calculation.

Figure 11: Fertility and Change Rate of Support Ratio for 2015-2035 (left, NTAs), 2015-2055 (middle, NTAs), 2014 to Steady State (right, the model)
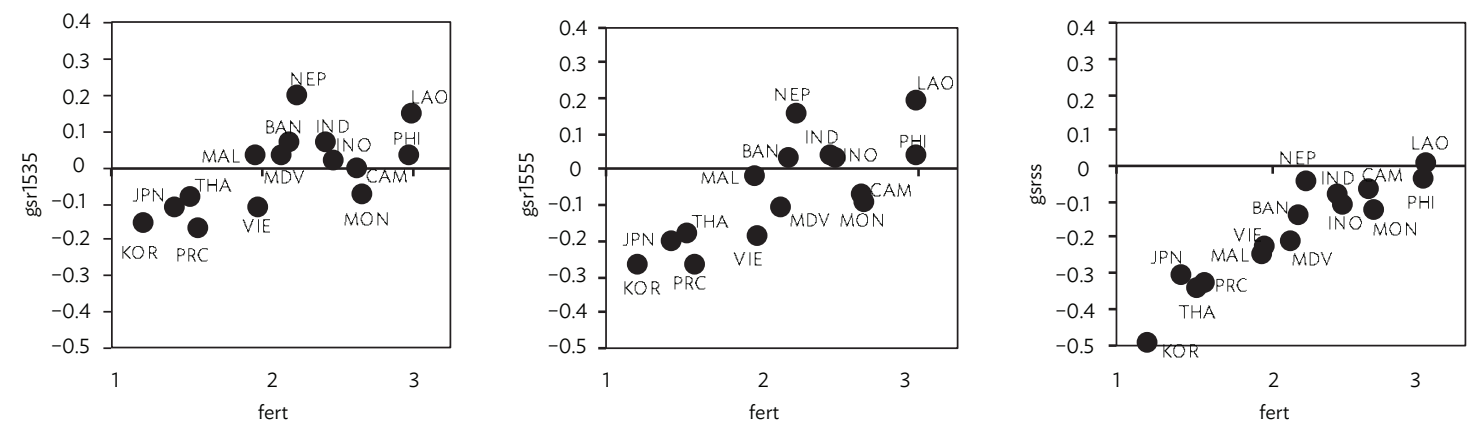

BAN = Bangladesh, CAM = Cambodia, IND = India, INO = Indonesia, JPN = Japan, $K O R=$ Republic of Korea, $L A O=$ Lao People's Democratic Republic, $M A L=$ Malaysia, $M L D=$ Maldives,$M O N=$ Mongolia, NEP = Nepal, NTAs = national transfer accounts, PHI = Philippines, PRC = People's Republic of China, PWT = Penn World Table, THA = Thailand, VIE = Viet Nam.

Sources: Authors' calculation; National Transfer Accounts; World Development Indicators. https://data.worldbank.org/datacatalog/world-development-indicators (accessed 5 September 2016).

\section{CONCLUSION}

We have shown that there are three conditions for a demography-driven middle-income trap, and our main finding is that Asian economies generally meet those conditions, especially in East and Southeast Asia. So far, low fertility caused rapid increase in support ratios and more demographic dividends in Asia, leading to faster catch-up with the frontier. But, for many countries in this region, this positive effect cannot be sustained for many decades to come.

Declining support ratios are a strong headwind for growth, leading to at least a "temporary" or "transitional" middle-income trap. So, we would like to emphasize that the "transition" may take decades, not years.

Policy implications for our analysis is straightforward. First, fertility decline should not be that fast and shocking to the economy. Second, fertility should come back to more sustainable levels in many Asian economies. Transfers to younger generations due to human capital investment are needed for continuing catch-up, but it may be too costly for some countries as too much "quantity-quality 
trade-off" leading to too low fertility, eroding the basis of catch-up itself. For example, it is well known that in East Asian economies, households spend substantial amounts of income in English language education. This may be to prepare their kids for the catch-up development, but this, at the same time, makes the private cost of having kids too high.

Therefore, as economies develop, the cost of human capital investment relative to income should become significantly cheaper to avoid the trap that may wait in the future. In the meantime, however, carefully extending retirement age, for example to 70, will certainly help alleviate the problems to some degree. 


\section{REFERENCES}

Acemoglu, Daron, Philippe Aghion, and Fabrizio Zilibotti. 2006. "Distance to Frontier, Selection, and Economic Growth.” Journal of the European Economic Association 4 (1): 37-74.

Aghion, Philippe, Peter Howitt, and David Mayer-Foulkes. 2005. "The Effect of Financial Development on Convergence: Theory and Evidence." Quarterly Journal of Economics 120 (1): 173-222.

Basu, Susanto, and David Weil. 1998. "Appropriate Technology and Growth.” Quaterly Journal of Economics 113 (4): 1025-54.

Becker, Gary S. 1960. "An Economic Analysis of Fertility." In Demographic and Economic Change in Developed Countries, edited by Gary S. Becker. Princeton: Princeton University Press.

Bloom, David E., David Canning, and Pia N. Malaney. 1999. "Demographic Change and Economic Growth in Asia." CID Working Paper No. 15.

Bloom, David E., and Jeffrey G. Williamson. 1997. "Demographic Transitions and Economic Miracles in Emerging Asia.” NBER Working Paper No. 6268.

Deaton, Angus S. and Christina H. Paxson. 1997. "The Effects of Economic and Population Growth on National Saving and Inequality.” Demography 34 (1): 97-114.

Feenstra, Robert C., Robert Inklaar, and Marcel P. Timmer. 2015. "The Next Generation of the Penn World Table." American Economic Review 105 (10): 3150-82. Available for download at www.ggdc.net/pwt.

Galor, Oded. 2011. Unified Growth Theory. Princeton: Princeton University Press.

Gill, Indermit Singh, and Homi Kharas. 2007. An East Asian Renaissance: Ideas for Economic Growth. Washington, DC: World Bank.

Ha, Joonkyung, and Sang-Hyop Lee. 2015. "Macroeconomic Consequences of Global Population Aging: A Dynamic General Equilibrium Analysis with Human Capital and Support Ratios." Manuscript.

-_- 2016. "Demographic Dividend and Asia's Economic Convergence Towards the US." The Journal of the Economics of Ageing 8: 28-41.

Han, Xuehui, and Shang-Jin Wei. 2016. "Re-examining the Middle-Income Trap Hypothesis (MITH): What to Reject and What to Revive?" CEPR Discussion Paper No. 10989.

Im, Fernando Gabriel, and David Rosenblatt. 2013. "Middle-Income Traps: A Conceptual and Empiral Survey." World Bank Policy Research Working Paper No. 6594.

Lee, Ronald, and Andrew Mason. 2010. "Fertility, Human Capital, and Economic Growth over the Demographic Transition." European Journal of Population 26 (2): 159-82. 
Lee, Ronald, Andrew Mason, and Timothy Miller. 2003. The Scandinavian Journal of Economics 105 (3): 339-57. http://onlinelibrary.wiley.com/doi/10.1111/1467-9442.t01-2-00002/full.

Lee, Ronald, Andrew Mason, and members of the national transfer accounts network. 2014. "Is Low Fertility Really a Problem? Population Aging, Dependency, and Consumption." Science (346): 229-34.

Lee, Sang-Hyop, Andrew Mason, and Donghyun Park. 2012. "Why Does Population Aging Matter So Much for Asia?" In Aging, Economic Growth, and Old-Age Security in Asia, edited by Donghyun Park, Sang-Hyop Lee, and Andrew Mason, 1-31. Cheltenham, United Kingdom and Northampton, MA: Edward Elgar.

Mason, Andrew, and Tomoko Kinugasa. 2008. "East Asian Economic Development: Two Demographic Dividends." Journal of Asian Economy 19 (5-6): 389-99.

Mason, Andrew, and Ronald Lee. 2007. "Transfers, Capital, and Consumption over the Demographic Transition." In Population Aging, Intergenerational Transfers and the Macroeconomy, edited by Robert Clark, Naohiro Ogawa, and Andrew Mason, 128-62. Cheltenham, United Kingdom: Edward Elgar.

Mason, Andrew, Ronald Lee, and Sang-Hyop Lee. 2010. "The Demographic Transition and Economic Growth in the Pacific Rim." In The Economic Consequences of Demographic Change in East Asia, edited by Takatoshi Ito and Andrew Rose. NBER-EASE, Volume 19, 19-55. Chicago: University of Chicago Press.

World Bank. World Development Indicators. https://data.worldbank.org/data-catalog/worlddevelopment-indicators.

Young, Alwyn. 1995. "The Tyranny of Numbers: Confronting the Statistical Realities of the East Asian Growth Experience.” The Quarterly Journal of Economics 110 (3): 641-80. 


\section{Population Aging and the Possibility of a Middle-Income Trap in Asia}

What happens to Asia if it gets too old before getting rich? In this paper, the authors explore the possibility that Asia faces a middle-income trap due to demographic factors. They find that many economies in East, South, and Southeast Asia satisfy conditions for a demography-driven middle-income trap. Analyses show that support ratio-the ratio of workers to consumers-matters for economic growth. But as the economy grows, fertility declines, ultimately leading to low support ratios and a lower speed of convergence, creating conditions for economic stagnation.

\section{About the Asian Development Bank}

ADB's vision is an Asia and Pacific region free of poverty. Its mission is to help its developing member countries reduce poverty and improve the quality of life of their people. Despite the region's many successes, it remains home to a large share of the world's poor. ADB is committed to reducing poverty through inclusive economic growth, environmentally sustainable growth, and regional integration.

Based in Manila, ADB is owned by 67 members, including 48 from the region. Its main instruments for helping its developing member countries are policy dialogue, loans, equity investments, guarantees, grants, and technical assistance. 